\title{
Screening for lower genital tract infections in women of reproductive age group attending a tertiary care hospital
}

\author{
Malathi Murugesan ${ }^{1}$, Vijayalakshmi Arumugam ${ }^{1}$, Nithya Gomatheeswari ${ }^{2}$, Sowmya $\mathbf{A V}^{3}$
}

\author{
${ }^{1}$ Department of Microbiology, Chengalpattu Medical College, Chengalpattu, Tamil Nadu, India \\ ${ }^{2}$ Department of Microbiology, Thoothukudi Government Medical College, Thoothukudi, Tamil Nadu, India \\ ${ }^{3}$ Department of Microbiology, Government Medical College, Omandurar Government Estate, Chennai, Tamil Nadu, \\ India
}

Received: 12 September 2016

Accepted: 07 October 2016

\author{
*Correspondence: \\ Dr. Malathi Murugesan, \\ E-mail: drmalathi13@gmail.com
}

Copyright: () the author(s), publisher and licensee Medip Academy. This is an open-access article distributed under the terms of the Creative Commons Attribution Non-Commercial License, which permits unrestricted non-commercial use, distribution, and reproduction in any medium, provided the original work is properly cited.

\begin{abstract}
Background: Lower genital tract infections are the major cause of gynecological morbidity and a great public health concern in India. Inadequate laboratory diagnostic facilities in all the levels of health care, limited resources in material and manpower, stigma and discrimination associated with RTI services are some of the reasons of lack of exact incidence/prevalence rate of RTI in India. Hence this study was conducted to provide a reliable laboratory based data on the occurrence of lower genital tract infections.

Methods: A prospective study was conducted on 110 women attending Gynecology OPD at a tertiary care teaching hospital over a period of one year (June 2014 to May 2015). After getting informed consent and brief history, vaginal swab and endocervical sample was collected and used for microscopic examination and culture. All the endocervical samples were subjected to Real Time PCR for detection of Chlamydia trachomatis.

Results: Among 110 samples, laboratory diagnosis of lower genital tract infections was positive in 43 subjects (39.09\%). By Real time PCR assay among the 110 samples, 9 (8.8\%) of the samples were positive for Chlamydia trachomatis infection. Candida sp., $(17,35.42 \%)$ was the most common organism identified followed by Escherichia coli $(10,20.83 \%)$.

Conclusions: Laboratory screening is must in all the symptomatic women in order to avoid the unnecessary treatment, which warrants the patients' reliability. Chlamydia trachomatis screening is mandatory for all the child bearing age group women to avoid consequences like PID and infertility.
\end{abstract}

Keywords: Laboratory diagnosis, Genital infections, Reproductive age group, RTI, STI

\section{INTRODUCTION}

Lower genital tract infections are the major cause of gynecological morbidity and a great public health concern in India. The infections affecting the lower genital tract includes sexually transmitted diseases such as Chlamydia, Gonorrhea, Trichomoniasis, Syphilis, endogenous infections such as vulvovaginal candidiasis or bacterial vaginosis and iatrogenic infections which are associated with medical procedures. ${ }^{1}$ WHO statistics indicate that the total number of new cases of Reproductive Tract Infections (RTI) in adults between the ages of 15 and 49 was estimated to be 498.9 million including lower genital tract infections. Among them are 105.7 million cases of Chlamydia trachomatis, 106.1 million cases of Neisseria gonorrhoeae and 276.4 million cases of Trichomonas vaginalis. ${ }^{2}$ The common causes of lower genital tract infections which presents with Discharge per vaginum are Chlamydia trachomatis, Candidiasis, Trichomoniasis, Bacterial vaginosis, Gonorrhea, Syphilis, Human papilloma virus (HPV) infection, Herpes simplex virus (HSV) infection, Lymphogranuloma venerum, Chancroid and other bacterial infections. $^{3}$ 
The gold standard method for the diagnosis of Candidiasis is culture with clinical correlation of symptoms like itching and burning micturition. For Trichomoniasis, the specific method is culture using Kupferberg`s STS medium or Modified Diamond medium. ${ }^{4}$ Diagnosis of Bacterial Vaginosis can be done either by Amsel criteria or Nugents' criteria. ${ }^{5}$ Nugent et al., made a scoring system ranged from 0 to 10 based on his criteria. The sensitivity and specificity is $90 \%$ and 94\% respectively. ${ }^{6}$ Culture is the "Gold Standard" for the definitive diagnosis of gonorrhoea. The sensitivity of culture is $85-95 \%$ in case of acute infection and the specificity is $100 \%$, whereas in chronic infections it is $50 \%$ sensitivity. ${ }^{7}$ In case of syphilis, the nonspecific test like VDRL, RPR are used for screening and specific tests are used for confirmatory. TPI test is the gold standard test and FTA-ABS is the standard reference test. ${ }^{8}$ The sensitivity of TPHA is 85 to $100 \%$ and the specificity is 98 to $100 \% .^{9}$

In females, the asymptomatic Chlamydial infection, if left untreated leads to Pelvic Inflammatory Disease (PID), infertility and its complications. Henceforth, screening women for Chlamydia trachomatis helps in prevention of PID, ectopic pregnancy and infertility. The gold standard test for diagnosing Chlamydia trachomatis infection is the detection of nucleic acid in samples i.e., Nucleic Acid Amplification Test (NAAT). Inadequate laboratory diagnostic facilities in all the levels of health care, limited resources in material and manpower, stigma and discrimination associated with RTI services are some of the reasons of lack of exact incidence/prevalence rate of RTI in India, which forms an important data tool for determining intervention and treatment strategies. ${ }^{10}$ Moreover, epidemiological studies in RTI are not abundant in South India. ${ }^{11}$ Hence this study was conducted to provide a reliable laboratory based data on the microbiological profile of lower genital tract infections. The main aim of the study is to isolate and to study the etiological agents of lower genital tract infections in women of reproductive age group and also to determine the proportion of Chlamydia trachomatis among the study group by Real-time PCR assay.

\section{METHODS}

A prospective study was conducted on 110 women attending Gynaecology OPD at a tertiary care teaching hospital over a period of one year from June 2014 to May 2015 .

The inclusion criteria were age group 18-45years, women with history of vaginal discharge, lower abdominal pain, itching, burning micturition and infertility.

The exclusion criteria were unmarried women, pregnancy, women on menstruation, women who have undergone hysterectomy, women on antimicrobial therapy, on chronic illness. After getting informed consent, brief history was obtained by structured questionnaire related to socio-demographic profile, presenting complaints and past history. Procedure for obtaining vaginal and endocervical swabs was explained to the patient beforehand.

Table 1: Methods used for the diagnosis of STI/RTI.

\begin{tabular}{|c|c|c|}
\hline $\begin{array}{l}\text { Name of } \\
\text { STI/RTI }\end{array}$ & $\begin{array}{l}\text { Preliminary } \\
\text { test }\end{array}$ & $\begin{array}{l}\text { Confirmatory } \\
\text { test }\end{array}$ \\
\hline $\begin{array}{l}\text { Candida } \\
\text { albicans }\end{array}$ & $\begin{array}{l}\text { Gram staining } \\
\text { KOH mount } \\
\text { Germ tube test }\end{array}$ & $\begin{array}{l}\text { Sabourards } \\
\text { dextrose agar } \\
\text { (Culture) } \\
\text { Dalmau plate } \\
\text { culture (For } \\
\text { speciation) }\end{array}$ \\
\hline $\begin{array}{l}\text { Trichomonas } \\
\text { vaginalis }\end{array}$ & $\begin{array}{l}\text { Saline Wet } \\
\text { mount }\end{array}$ & 1 \\
\hline $\begin{array}{l}\text { Bacterial } \\
\text { vaginosis }\end{array}$ & $\begin{array}{l}\text { Gram staining - } \\
\text { Nugent } \\
\text { scoring }\end{array}$ & $\begin{array}{l}\text { Gram staining - } \\
\text { Nugent } \\
\text { scoring }\end{array}$ \\
\hline $\begin{array}{l}\text { Neisseria } \\
\text { gonorrheae }\end{array}$ & $\begin{array}{l}\text { Gram staining - } \\
\text { For intracellular } \\
\text { Gram negative } \\
\text { diplococci } \\
\text { Transport media }\end{array}$ & $\begin{array}{l}\text { Culture in } \\
\text { modified Thayer } \\
\text { Martin medium } \\
\text { followed by } \\
\text { placement in } \mathrm{CO} 2 \\
\text { jar in the field }\end{array}$ \\
\hline $\begin{array}{l}\text { Chlamydia } \\
\text { trachomatis }\end{array}$ & - & $\begin{array}{l}\text { Real Time PCR } \\
\text { assay }\end{array}$ \\
\hline Genital ulcer & $\begin{array}{l}\text { Gram staining - } \\
\text { Pus cells, } \\
\text { Organisms }\end{array}$ & $\begin{array}{l}\text { Culture according } \\
\text { to the Gram } \\
\text { staining } \\
\text { morphology }\end{array}$ \\
\hline $\begin{array}{l}\text { Aerobic } \\
\text { culture }\end{array}$ & $\begin{array}{l}\text { MacConkey } \\
\text { agar plate and } \\
\text { blood agar plate } \\
\text { and incubated at } \\
37^{0} \mathrm{C} \text { for } 24 \\
\text { hours with } 10 \% \\
\mathrm{CO}_{2} \text {. }\end{array}$ & $\begin{array}{l}\text { Organism was } \\
\text { identified by } \\
\text { Colony } \\
\text { morphology, } \\
\text { Gram staining, } \\
\text { Catalase test, } \\
\text { Oxidase test and } \\
\text { other biochemical } \\
\text { reactions. }\end{array}$ \\
\hline
\end{tabular}

In lithotomy position, under aseptic precautions, vaginal discharge was collected for wet mount, then three swabs from posterior vaginal fornix with the help of sterile cotton swabs and one sample from cervical os using Ayer`s spatula was collected. Vaginal discharge was immediately utilized for performing wet mount and Gram staining.

The vaginal swabs were transported to the diagnostic microbiology laboratory as early as possible for culture. A sterile swab was then introduced into the cervix to remove the cervical mucus secretions. The endocervical brush was inserted 1 to $2 \mathrm{~cm}$ into the endocervical canal, rotated against the wall for 10 to 30 seconds, withdrawn without touching the vaginal surfaces and then placed in the appropriate transport medium. One endocervical brush was inoculated immediately in Modified Thayer 
Martin medium and incubated in candle extinction jar. Another endocervical brush was inoculated in a sterile aliquot tube containing $2 \mathrm{ml}$ of $99 \%$ ethanol for detecting Chlamydial nucleic acid by Real-time PCR. The aliquot tubes were carried in an ice-packed carrier and stored in deep freezer $\left(-20^{\circ} \mathrm{C}\right)$ immediately.

Real time PCR was done by HELINI PureFast®Bacterial DNA mini spin purification kit, HELINI Chlamydia trachomatis Real- time PCR kit, Instrument used was Agilent MX3000P Real time PCR machine. Endogenous control = FAM channel (Human RNase $\mathrm{P}$ gene), Chlamydia trachomatis = FAM channel. Real time interpretation was done by the amplification plots and by the ct value.

Data was formulated in terms of frequency distribution for different variables. As the data are categorical variable, Fischer test was employed as test of significance for testing associations. Multivariate logistic regression model for statistically significant predictors of lower genital tract infections were also tested. The data was analysed using Epi-Info software (7.1.0.6 version; Center for disease control, USA) and Microsoft Excel 2010.

\section{RESULTS}

A total of 110 samples were collected over a period of one year which included vaginal swab and endocervical swab. The samples were processed and the results are shown as follows. Age wise distributions of the subjects were analysed. The range of age was 20 to 43 years. The median age was 26 . The majority $(43.63 \%)$ of the study population were in the age group of 21 to 25 years, followed by the age group of 26 to 30 years (33.64\%). Among them, parity wise distribution showed that the majority of the study group $(49.1 \%)$ had two children. $9.09 \%$ was nulliparous women and $2.73 \%$ had history of abortion/still born. Discharge per vaginum (82, 74.55\%) was the major presenting complaint, followed by abdomen pain $(56.36 \%)$, itching $(23.64 \%)$ and then burning micturition (17.21\%). Among 110 samples, laboratory diagnosis of lower genital tract infections was positive in 43 subjects (39.09\%). Among 43 subjects who had laboratory findings for lower genital tract infections, $36(83.72 \%)$ presented with single infection and 7 $(16.28 \%)$ were presented with mixed infections. Laboratory diagnosis of bacterial vaginosis $(6.97 \%$ positivity) was based on Nugent's score.

Candida sp. $(17,35.42 \%)$ was the most common organism identified followed by Escherichia coli (10, 20.83\%). Among the isolated Candida sp., Candida albicans accounted for $8(47.05 \%)$, Candida glabrata 3 (17.35\%), Candida tropicalis $3(17.35 \%)$ and Candida kefyr $3(17.35 \%)$. By Real time PCR assay among the 110 samples, $9(8.8 \%)$ of the samples were positive for C.trachomatis infection. The distribution of the various microbiological agents causing lower genital tract infections in the study population is depicted in the Table 1.

Table 1: Distribution of study group with positive laboratory findings for lower genital tract infections.

\begin{tabular}{|c|c|c|c|}
\hline $\begin{array}{l}\text { Type of } \\
\text { infections }\end{array}$ & $\begin{array}{l}\text { Cases positive for } \\
\text { laboratory diagnosis }\end{array}$ & $\begin{array}{l}\text { No. } \\
(n=43)\end{array}$ & $\%$ \\
\hline \multirow{8}{*}{$\begin{array}{l}\text { Single } \\
\text { infections }\end{array}$} & Candida sp. & 12 & 27.91 \\
\hline & Chlamydia trachomatis & 5 & 11.63 \\
\hline & $\begin{array}{l}\text { Trichomonas vaginalis } \\
\text { (TV) }\end{array}$ & 3 & 6.97 \\
\hline & Bacterial vaginosis (BV) & 3 & 6.97 \\
\hline & Staphylococcus aureus & 1 & 2.33 \\
\hline & Streptococcus sp. & 1 & 2.33 \\
\hline & Escherichia coli & 7 & 16.28 \\
\hline & Klebsiella pneumoniae & 4 & 9.30 \\
\hline \multirow{7}{*}{$\begin{array}{l}\text { Mixed } \\
\text { infections }\end{array}$} & Candida + Chlamydia & 1 & 2.33 \\
\hline & $\begin{array}{l}\text { Candida }+ \\
\text { Staphylococcus aureus }\end{array}$ & 1 & 2.33 \\
\hline & $\begin{array}{l}\text { Candida + Escherichia } \\
\text { coli }\end{array}$ & 2 & 4.65 \\
\hline & $\begin{array}{l}\text { Candida + Chlamydia + } \\
\text { Escherichia coli }\end{array}$ & 1 & 2.33 \\
\hline & $\begin{array}{l}\text { Chlamydia + Citrobacter } \\
\text { koseri }\end{array}$ & 1 & 2.33 \\
\hline & $\begin{array}{l}\text { Chlamydia + Klebsiella } \\
\text { pneumoniae }\end{array}$ & 1 & 2.33 \\
\hline & Total & 43 & 100 \\
\hline
\end{tabular}

Candida sp., was the commonest agent $(75 \%)$ causing lower genital tract infections in study group $\leq 30$ years and aerobic bacterial agents were the commonest agent among >30 years age group study population whereas, Poly microbial infections were seen only in age group $\leq 30$ years (Table 2). Over all, lower genital tract infections were common among women $\leq 30$ years with significant $\mathrm{p}$ value (0.0037). Candida $\mathrm{sp}$. was the most common agent affecting all the parity groups with majority of study group belonging to L1 (41.67\%). Aerobic bacteria was commonly identified among all groups of parous women (L1, L2,>L2). In nulliparous women $(n=10)$, Candidiasis $(n=1)$, TV and BV each $(n=1)$ and polymicrobial infections $(n=2)$ are seen. Over all, lower genital tract infections were common among the women with multi parity with significant $\mathrm{p}$ value (0.0797) (Table 3).

\section{DISCUSSION}

Our country is in a state of epidemiological and demographical transition where morbidity and mortality rates may differ from previous demographic studies. In the last few years, community based studies on reproductive tract infections have been carried out in various parts of our country. Yet, South Indian studies are not widely available.

Out of 110 vaginal swabs which were subjected to wet mount microscopy, Gram staining, aerobic and anaerobic culture, fungal culture and the endocervical swabs which 
were subjected to culture for $N$. gonorrhea and Real time PCR assay for the detection of C.trachomatis, 43 $(39.09 \%)$ of the cases were positive for any one of the agents commonly causing lower genital tract infections. This correlates well with a study conducted in an urban health centre, where the prevalence of RTI was $34.3 \%$ based on the laboratory findings whereas $40.4 \%$ based on only the symptoms. ${ }^{12}$ Prabha MLS et al. have estimated the prevalence of $33.1 \%$ in their study population. ${ }^{13}$ The higher prevalence in urban areas is due to knowledge and awareness about genital tract infections and easy accessibility to tertiary care centres.

Table 2: Distribution of laboratory diagnosed cases in relation to age group.

\begin{tabular}{|c|c|c|c|c|c|c|c|c|c|c|c|c|}
\hline \multirow{2}{*}{ Age } & \multicolumn{2}{|c|}{$\begin{array}{l}\text { Candida } \\
\text { sp. }\end{array}$} & \multicolumn{2}{|c|}{$\begin{array}{l}\text { Chlamydia } \\
\text { trachomatis }\end{array}$} & \multicolumn{2}{|c|}{$\begin{array}{l}\text { Trichomonas } \\
\text { vaginalis }\end{array}$} & \multicolumn{2}{|c|}{$\begin{array}{l}\text { Bacterial } \\
\text { vaginosis }\end{array}$} & \multicolumn{2}{|c|}{$\begin{array}{l}\text { Aerobic } \\
\text { bacteria }\end{array}$} & \multicolumn{2}{|c|}{$\begin{array}{l}\text { Poly } \\
\text { microbial }\end{array}$} \\
\hline & No & $\%$ & No & $\%$ & No & $\%$ & No & $\%$ & No. & $\%$ & No & $\%$ \\
\hline$\leq 30$ years & 9 & 75 & 5 & 100 & 2 & 66.67 & 3 & 100 & 7 & 53.85 & 7 & 100 \\
\hline$>30$ years & 3 & 25 & 0 & 0 & 1 & 33.33 & 0 & 0 & 6 & 46.15 & 0 & 0 \\
\hline Total & 12 & 100 & 5 & 100 & 3 & 100 & 3 & 100 & 13 & 100 & 7 & 100 \\
\hline
\end{tabular}

Table 3: Distribution of laboratory diagnosed cases in relation with parity.

\begin{tabular}{|c|c|c|c|c|c|c|c|c|c|c|c|c|}
\hline \multirow{2}{*}{ Parity } & \multicolumn{2}{|c|}{$\begin{array}{l}\text { Candida } \\
\text { Species }\end{array}$} & \multicolumn{2}{|c|}{$\begin{array}{l}\text { Chlamydia } \\
\text { Trachomatis }\end{array}$} & \multicolumn{2}{|c|}{$\begin{array}{l}\text { Trichomonas } \\
\text { vaginalis }\end{array}$} & \multicolumn{2}{|c|}{$\begin{array}{l}\text { Bacterial } \\
\text { Vaginosis }\end{array}$} & \multicolumn{2}{|c|}{$\begin{array}{l}\text { Aerobic } \\
\text { bacteria }\end{array}$} & \multicolumn{2}{|c|}{$\begin{array}{l}\text { Poly } \\
\text { microbial }\end{array}$} \\
\hline & No. & $\%$ & No. & $\%$ & No. & $\%$ & No. & $\%$ & No. & $\%$ & No. & $\%$ \\
\hline Nulliparous & 1 & 8.33 & 0 & 0 & 1 & 33.33 & 1 & 33.33 & 0 & 0 & 2 & 28.56 \\
\hline Abortion & 0 & 0 & 0 & 0 & 0 & 0 & 1 & 33.33 & 1 & 7.69 & 1 & 14.29 \\
\hline $\begin{array}{l}\text { One child } \\
\text { (L1) }\end{array}$ & 5 & 41.67 & 2 & 40 & 0 & 0 & 1 & 33.33 & 4 & 30.77 & 3 & 42.86 \\
\hline $\begin{array}{l}\text { Two child } \\
\text { (L2) }\end{array}$ & 4 & 33.33 & 3 & 60 & 2 & 66.67 & 0 & 0 & 5 & 38.46 & 1 & 14.29 \\
\hline $\begin{array}{l}>2 \text { child } \\
(>\mathrm{L} 2)\end{array}$ & 2 & 16.67 & 0 & 0 & 0 & 0 & 0 & 0 & 3 & 23.08 & 0 & 0 \\
\hline Total & 12 & 100 & 5 & 100 & 3 & 100 & 3 & 100 & 13 & 100 & 7 & 100 \\
\hline
\end{tabular}

The findings of laboratory diagnosed cases were evaluated and it was estimated that in our study about $83.72 \%$ had single infection and $16.28 \%$ had mixed infections. The differences in the figures in our study with comparison to other studies is due to lesser sample size, hospital based study while all the comparative study groups are community based studies. ${ }^{13,14}$

Bacterial vaginosis, as such is a clinical term diagnosed by Amsel criteria. The sensitivity and specificity of Amsel criteria is $37 \%$ and $99 \%$ respectively (Sha BE et al. ${ }^{14}$ We have estimated $6.97 \%$ of $\mathrm{BV}$ cases by the gold standard laboratory diagnostic method i.e., Nugent scoring. There is a low level of estimation in our study when compared to other studies (Rohit Chawla et al., $32.86 \%$ and Modak $\mathrm{T}$ et al., 24\%). ${ }^{16,17}$ Since only laboratory method was employed, correlation between Amsel criteria method and Nugent scoring method could not be obtained in our study. The consequences of BV include abortion, still birth; preterm deliveries and co infections are also more common. Hence in addition to screening of high risk groups, all child bearing age group should be screened for BV to avoid such complications.

The agents causing the lower genital tract infections were analyzed individually and it was estimated that $35.42 \%$ were Candida sp., among them, $47.05 \%$ Candida albicans, $17.65 \%$ Candida glabrata, $17.65 \%$ Candida tropicalis, $17.65 \%$ C. kefyr. There is slightly increased prevalence when compared to other studies. Jindal et al., estimated $23.4 \%$ culture positive for Candida sp., with $74.4 \%$ of Candida albicans, $11 \%$ Candida glabrata, $6 \%$ Candida tropicalis, $3.6 \%$ Candida krusei and $2.43 \%$ Candida parapsilosis and Candida guillermondi each. ${ }^{18}$ Anis ahmad et al., estimated $20.47 \%$ prevalence of Candida sp., with Candida glabrata $36.7 \%$, Candida parapsilosis $10.2 \%$, Candida tropicalis $2.8 \%$, Candida kefyr $1.8 \%$ and Candida krusei $1.4 \% .{ }^{19} 75 \%$ of Candida isolates affected $\leq 30$ years which gets correlated with a study conducted by Sujith D.Rathod et al. ${ }^{20}$ Vulvovaginal candidiasis (VVC), as such is not a sexually transmitted disease but the majority of women presenting with leucorrhea is diagnosed with VVC. Non albicans species 
of Candida is in increased prevalence for the recent years. The risk of recurrent infections is more common if the infection is not properly treated. Chlamydia trachomatis $(18.75 \%)$ was the proportion obtained from our study. The prevalence rate of C.trachomatis by PCR is $7.04 \%$ (Dwibedi et al.,) and $23 \%$ (Saluja D et al). ${ }^{26}$ The increased proportion of Chlamydia trachomatis in our study is attributed to the molecular diagnostic technique employed i.e., Real-time PCR detection method which has higher sensitivity when compared to other methods. Jaton $\mathrm{K}$ et al., have identified that the sensitivity and specificity of Real time PCR is $95.7 \%$ and $100 \%$ respectively. ${ }^{23}$ As Chlamydia trachomatis presents as asymptomatic infection, untreated genital tract infection can lead to ramifications for the childbearing age group women. It is a must to screen all the child bearing age group women for C.trachomatis infection with cost effective methods. The available diagnostic techniques like ELISA are not a reliable indicator and at least in resource rich areas, molecular methods are advisable to estimate the exact prevalence of C.trachomatis infection. Similar to others findings, Chlamydia trachomatis $(100 \%)$ affected the age group $\leq 30$ years in our study. ${ }^{24,25}$ The reasons for the significance of this age group and C.trachomatis infections is due to early coitarche, inconsistent use of barrier methods and multiple sexual partners. There is a need to educate the young sexually active females to avoid risky sexual practices and to undergo periodic screening for C.trachomatis. Health programmes should be implemented to screen the clinically silent C.trachomatis infections at an early age ( $<25$ years) to safeguard the reproductive health of women.

$6.25 \%$ of lower genital infections were contributed by Trichomonas vaginalis in our study. This is in accordance with $8.5 \%$ estimated by Madhivannan et al. ${ }^{26}$ As TV is a treatable infection, the consequences like preterm deliveries, transmissibility to sex partner, increased exposure for other sexually transmitted infections can be prevented when appropriate etiological diagnosis is obtained. In developing countries, the screening modalities are mainly aimed at high risk groups leaving behind the study population belonging to community, where the exact prevalence data is submerging. In our study, only wet mount method was used as the modality of diagnosis of TV. The sensitivity of wet mount method is $55 \%$ (Sood s et al.) Shetkar S has estimated that the prevalence of TV by wet mount and broth culture method was $0.5 \%$ and $3 \%$ respectively. $^{27,28}$ There is an underestimation of the TV cases in our study and if broth culture method has been employed, the actual data could be obtained. However, our estimation reflects the methodology employed in a developing country like India, where wet mount is the universal method of screening (NACO guidelines).

Among the aerobic bacterial infections, 6.25\% (4.66\% as single infection, $1.59 \%$ as mixed infection) caused by Gram-positive cocci and $33.33 \%(25.58 \%$ as single infection, $7.75 \%$ as mixed infection) by Gram negative bacilli. The difference between colonization and infections was established by the presence of active symptoms, presence of pus cells in wet mount and Gram staining, presence of inflammation in Pap smear findings and remission of symptoms following treatment.

In our study, the age group $\leq 30$ years were more prone for poly microbial infections $(16.28 \%)$ with significant $p$ value of 0.0037 . The findings of parity analysis in our study showed that mixed infections were equally distributed in almost all the types of parity groups.

\section{CONCLUSION}

The findings of our study have shown that laboratory screening is must in all the symptomatic women in order to avoid the unnecessary treatment, which warrants the patients' reliability. The symptomatic treatment should be supported by the etiological diagnosis to know the exact burden and distribution of various agents causing RTI. As Chlamydia trachomatis is the most common cause of treatable RTI worldwide, screening is mandatory for all the child bearing age group women to avoid consequences like PID and infertility. Hence it is recommended to take a prudent action on implementing a nationwide screening programme for Chlamydia trachomatis.

\section{Funding: No funding sources Conflict of interest: None declared \\ Ethical approval: The study was approved by the Institutional Ethics Committee}

\section{REFERENCES}

1. WHO. Sexually transmitted and other reproductive tract infections. Available from: http://www.who.int/reproductivehealth/publications/r tis/9241592656/en/.

2. Reproductive Tract Infections Reproductive Health Epidemiology Series Module 3 epi_module_03a_tag508.pdf. Available from: https://www.cdc.gov/reproductivehealth/productspub s/pdfs/epi_module_03a_tag508.pdf.

3. Malhotra M, Sood S, Mukherjee A, Muralidhar S, Bala M. Genital Chlamydia trachomatis: An update. Indian J Med Res. 2013;138(3):303-16.

4. Khatoon R, Jahan N, Ahmad S, Khan HM, Rabbani T. Comparison of four diagnostic techniques for detection of Trichomonas vaginalis infection in females attending tertiary care hospital of North India. Indian J Pathol Microbiol. 2015;58(1):36-9.

5. Amsel R, Totten PA, Spiegel CA, Chen KC, Eschenbach D, Holmes KK. Nonspecific vaginitis. Diagnostic criteria and microbial and epidemiologic associations. Am J Med. 1983;74(1):14-22.

6. Nugent RP, Krohn MA, Hillier SL. Reliability of diagnosing bacterial vaginosis is improved by a 
standardized method of gram stain interpretation. J Clin Microbiol. 1991;29(2):297-301.

7. Schmale JD, Martin JE, Jr., Domescik G. OBservations on the culture diagnosis of gonorrhea in women. JAMA. 1969;210(2):312-4.

8. Health AGD of. Syphilis Laboratory Case Definition (LCD). Australian Government Department of Health; Available from: http://www.health.gov.au/internet/main/publishing.n sf/Content/cda-phln-syphilis.htm.

9. Naidu NK, Bharucha ZS, Sonawane V, Ahmed I. Comparative study of Treponemal and nonTreponemal test for screening of blood donated at a blood center. Asian J Transfus Sci. 2012;6(1):32-5.

10. Ray K, Bala M, Bhattacharya M, Muralidhar S, Kumari M, Salhan S. Prevalence of RTI/STI agents and HIV infection in symptomatic and asymptomatic women attending peripheral health set-ups in Delhi, India. Epidemiol Infect. 2008;136(10):1432-40.

11. Nagarkar A, Mhaskar P. A systematic review on the prevalence and utilization of health care services for reproductive tract infections/sexually transmitted infections: Evidence from India. Indian J Sex Transm Dis. 2015;36(1):18-25.

12. Community-Based Study of Reproductive Tract Infections Among Women of the Reproductive Age Group in the Urban Health Training Centre Area in Hubli, Karnataka. Available from: http://www.ncbi.nlm.nih.gov/pmc/articles/PMC3326 $805 /$.

13. Prabha MLS, Sasikala G, Bala S. Comparison of syndromic diagnosis of reproductive tract infections with laboratory diagnosis among rural married women in Medak district, Andhra Pradesh. Indian J Sex Transm Dis. 2012;33(2):112-5.

14. Carr PL, Felsenstein D, Friedman RH. Evaluation and Management of Vaginitis. J Gen Intern Med. 1998;13(5):335-46.

15. Sha BE, Chen HY, Wang QJ, Zariffard MR, Cohen MH, Spear GT. Utility of Amsel criteria, Nugent score, and quantitative PCR for Gardnerella vaginalis, Mycoplasma hominis, and Lactobacillus spp. for diagnosis of bacterial vaginosis in human immunodeficiency virus-infected women. J Clin Microbiol. 2005;43(9):4607-12.

16. Chawla R, Bhalla P, Chadha S, Grover S, Garg S. Comparison of Hay's criteria with Nugent's scoring system for diagnosis of bacterial vaginosis. BioMed Res Int. 2013;2013:365194.

17. Modak T, Arora P, Agnes C, Ray R, Goswami S, Ghosh P, et al. Diagnosis of bacterial vaginosis in cases of abnormal vaginal discharge: comparison of clinical and microbiological criteria. J Infect Dev Ctries. 2011;5(5):353-60.

18. Jindal N, Gill P, Aggarwal A. An epidemiological study of vulvovaginal candidiasis in women of childbearing age. Indian J Med Microbiol. 2007;25(2):175.

19. Ahmad A, Khan AU. Prevalence of Candida species and potential risk factors for vulvovaginal candidiasis in Aligarh, India. Eur J Obstet Gynecol Reprod Biol. 2009;144(1):68-71.

20. Rathod SD, Klausner JD, Krupp K, Reingold AL, Madhivanan P. Epidemiologic features of Vulvovaginal Candidiasis among reproductive-age women in India. Infect Dis Obstet Gynecol. 2012;2012:859071.

21. Dwibedi B, Pramanik J, Sahu P, Kar S, Moharana T. Prevalence of genital Chlamydia infection in females attending an Obstetrics and Gynecology outpatient department in Orissa. Indian J Dermatol Venereol Leprol. 2009;75(6):614.

22. Patel AL, Sachdev D, Nagpal P, Chaudhry U, Sonkar SC, Mendiratta SL, et al. Prevalence of Chlamydia infection among women visiting a gynaecology outpatient department: evaluation of an in-house PCR assay for detection of Chlamydia trachomatis. Ann Clin Microbiol Antimicrob. 2010;9:24.

23. Jaton K, Bille J, Greub G. A novel real-time PCR to detect Chlamydia trachomatis in first-void urine or genital swabs. J Med Microbiol. 2006;55(Pt12):1667-74.

24. Arinze AUH, Onyebuchi NV, Isreal J. Genital chlamydia trachomatis infection among female undergraduate students of University of Port Harcourt, Nigeria. Niger Med J J Niger Med Assoc. 2014;55(1):9-13.

25. Mawak JD, Dashe N, Agabi YA, Panshak BW. Prevalence of Genital Chlamydia Trachomatis Infection among Gynaecologic Clinic Attendees in Jos, Nigeria. Shiraz E-Med J. 2011;12(2):100-6.

26. Madhivanan $\mathrm{P}$, Krupp $\mathrm{K}$, Hardin J, Karat C, Klausner JD, Reingold AL. Simple and inexpensive point-of-care tests improve diagnosis of vaginal infections in resource constrained settings. Trop Med Int Health TM IH. 2009;14(6):703-8.

27. Sood S, Kapil A. An update on Trichomonas vaginalis. Indian J Sex Transm Dis AIDS. 2008 Jan 1;29(1):7.

28. Shetkar S.Role of polymerase chain reaction (PCR) in the diagnosis of Trichomonas vaginalis infection in HIV infected patients. Jour Scien and Innov Rese. 2013;2(6):983-7.

Cite this article as: Murugesan M, Arumugam V, Gomatheeswari N, Sowmya AV. Screening for lower genital tract infections in women of reproductive age group attending a tertiary care hospital. Int J Reprod Contracept Obstet Gynecol 2016;5:3987-92. 